\title{
Através do espelho: máquina, cinema e modernidade
}

\author{
Mariana Domingues da Costa*
}

\section{Resumo}

O artigo objetiva analisar os filmes Metropolis, Playtime, Matrix e Ela, para, assim, articular o cinema como linguagem com os avanços tecnológicos operados na modernidade, além de identificar como os avanços técnicos do cinema expressaram os impactos variados quanto a uma reconfiguração da sociedade. As representações cinematográficas, nesse sentido, têm a capacidade de, ao inventar a própria realidade, fabular e expressar de maneira radical como a tecnologia invade a vida da sociedade e da subjetividade de cada indivíduo. Os filmes selecionados para análise, dessa forma, explicitam tal relação de diferentes maneiras e em distintos contextos históricos.

Palavras-chave: cinema, modernidade, máquina

\section{Abstract}

The aim of this paper is to analyze the films Metropolis, Playtime, Matrix and Ela, and so articulate the language of cinema with the technological advances of modernity. Beyond this goal, this paper also aims to identify how these technological advances expressed the many impacts related to a reshaping of society. The cinematic representations, in this sense, are able to express in a radical fashion how technology pervades life in society and each person's subjectivity by inventing reality itself. The films selected for analysis explain such relationship in different ways and in different historical contexts.

Key Words: cinema, modernity, machine

\section{Introdução}

O cinema pode ser caracterizado, fundamentalmente, como um meio de espelhamento da realidade a partir da utilização da máquina. Espelhamento esse, no entanto, que não deve ser traduzido como uma pretensão em captar uma dada realidade em suas dimensões supostamente mais cruas. Como toda manifestação artística, o cinema também está marcado por uma determinada forma de apreensão subjetiva da realidade, e é nesse aspecto que reside sua dimensão propriamente artística. O uso da técnica como meio de construção da realidade, por sua vez, faz com

Graduanda em Ciências Sociais pela Universidade Federal do Amazonas (UFAM). E-mail: marianacosta449@gmail.com. 
que algo até então inédito do ponto de vista da percepção ganhe cada vez mais corpo no mundo moderno, inicialmente com a fotografia e, posteriormente, por meio do cinema (Benjamin, 2012). O problema do realismo, nesse sentido, também se faz presente no cinema. Não é difícil identificar ao longo da sua história um conjunto de filmes que se voltam para a questão da máquina ou da mecanização da sociedade como uma forma de reflexão acerca do próprio cinema.

Metropolis (2026), de Fritz Lang, pode ser identificado como o momento inaugural de certa tradição na história do cinema. Embora o fecho do filme aponte para um acordo apaziguador entre o "cérebro" (o industrial) e os "braços" (os operários) da sociedade por meio da ação sentimental do "coração", o enfoque central da trama não deixa de recair no processo de mecanização da sociedade e seus efeitos nas diversas dimensões da vida. O realce conferido ao aspecto sentimental apenas reforça esse papel assumido pela máquina a afetar as diferentes dimensões da existência humana. Desde então, o cinema, que toma a própria máquina como seu suporte, não deixará de dramatizar a problemática relação do mecanismo homemmáquina.

\section{O pensar e o agir}

O fato de Metropolis ser um filme a abordar a relação homem-máquina o torna relevante em função de o cinema ser ele mesmo uma forma de manifestação artística ancorada na máquina (Hansen, 2004). Ambientado em uma cidade futurista no ano de 2026, a cidade de Metropolis está cindida em dois mundos: entre aqueles que habitam os lugares mais altos e solares, de um lado, e os operários a residirem no mundo soturno do subsolo, de outro. A relação homem-máquina converte-se em alvo central da narrativa. O relógio exibido logo na abertura do filme surge para marcar o tempo do trabalho dos operários na fábrica, uma engrenagem mecânica, portanto, a ritmar a vida daqueles destinados a operarem máquinas, como se fossem delas meros apêndices. Com movimentos repetitivos e compassados, a troca de turno apresentada no início do filme revela o grau de "moldagem" então operado pelas máquinas sobre 
os corpos disciplinados. Os operários, exauridos de suas energias, saem da fábrica cabisbaixos, exaustos, mas enfileirados e em perfeita sincronia em seus movimentos.

Os espaços do subsolo destinam-se às habitações dos operários, delineadas no filme de forma tosca, tal como uma vila medieval a amontoar pequenas casas com janelas estreitas. O cenário expressionista do filme é destinado a distorcer propositalmente a realidade, fazendo sobrepor-se passado e futuro. Já o "Clube dos Filhos", por seu turno, revela ambientes solares, ajardinados e luxuosos, com teatros e biblioteca, locais onde a prática de esportes é valorizada;, portanto, o corpo parece apresentar-se distante dos efeitos perversos das máquinas em função de uma proximidade maior com a natureza. Todo o local é fortificado com altos muros a indicar certo isolamento daqueles privilegiados que ali residem, longe, portanto, da dura realidade vivenciada no restante da cidade. A despeito de tais diferenças de ordem social, a cidade mostra-se moderna do ponto de vista tecnológico, sendo a indústria o cérebro de toda aquela engrenagem a estruturar a sociedade. A cena dos operários a manuseando as máquinas tal como um bailado bem ordenado insinua uma suposta harmonia a caracterizar uma sociedade mecanizada de ponta a ponta (Adorno, 2007).

Mas a marca das diferenças sociais estampa-se também nas roupas e vestimentas utilizadas por uns e por outros naquela estrutura social fortemente hierarquizada. O traje dos operários resume-se a um macacão padronizado, diferente daqueles trajes utilizados por membros dos estratos sociais mais privilegiados a exibir modelos variados de roupas conforme cada ocasião. A indistinção das roupas dos operários os transforma em massa informe, enquanto os modelos que paramentam os setores sociais mais elitizados os dotam de certa individualidade. Quando o personagem principal da trama, o jovem e atlético Freder, filho do dono de uma grande indústria, enamora-se de Maria, uma operária, precisamente no momento em que ela aparece por engano com um bando de crianças naquele ambiente ajardinado, a trama do filme parece ser acionada. Conforme ressalta Marshall Berman ao analisar a primeira parte do Fausto, de Goethe, o mundo dos afetos pode ser bastante expressivo para se perceber as eventuais mudanças a serem operadas dentro de uma determinada sociedade (Berman, 2007, p. 65). Mas, se na obra de Goethe, a 
aproximação entre Fausto e a jovem e Gretchen é um indicativo do fim daquele ambiente tradicional próprio de pequenas comunidades quase medievais, em Metropolis, por sua vez, o afeto entre o jovem e herdeiro Freder e a Maria insinua uma reversão de uma sociedade fria e industrializada rumo ao ambiente de comunidade.

Maria, por seu turno, parece possuir certa ascendência sobre os operários por motivos de ordem religiosa ao exercer o papel de sacerdotisa. Freder, sob os efeitos e impactos de seu encantamento por Maria, decide procurá-la, abandonando seu mundo recluso e, assim, mostra-se disposto a enfrentar o mundo dominado pelas máquinas. Em sua busca, o jovem herdeiro presencia um grave acidente com uma das máquinas, acidente este que vem a ocasionar a morte de alguns operários. A visão de Freder da máquina a "engolir" os operários o faz lembrar do lendário monstro Moloc da antiga sociedade egípcia a devorar os seres humanos em sacrifício. Em função do tal acidente, o pai de Freder decide demitir seu gerente e encarregado imediato, Josaphat.

A importância de Josaphat para a trama se dá quando, sentindo-se injustiçado pela culpa do acidente, tenta suicidar-se. Freder o impede a tempo de cometer tal desatino e, assim, resolve investigar mais de perto os motivos daquele acidente, o que demonstra o seu distanciamento e alheamento quanto aos modos de organização e de produção da riqueza por ele mesmo desfrutada. É quando Freder resolve trocar de lugar com um dos operários da fábrica de seu pai. Mas o trabalho exaustivo junto ao maquinário logo provoca fadiga no atlético Freder que, por isso, quase causa um sério acidente em uma das máquinas, uma geringonça dotada de duas hastes móveis a lembrar os ponteiros de um relógio.

Vale salientar aqui, por sua vez, as opções então tomadas pelo operário que trocou de lugar com Freder. Com as roupas do jovem herdeiro e com um bom dinheiro no bolso, o operário toma o lugar de Freder e decide desfrutar de uma vida mundana que jamais poderia ter. Nenhuma consciência de classe parece aflorar de tais escolhas tomadas pelo operário deslumbrado. Comporta-se como se fosse um membro das classes privilegiadas ao desfrutar de bebidas e de mulheres. Nesse sentido, os possíveis efeitos e consequências de uma sociedade mecanizada se faz sentir não só sobre os operários, tal como indicado na abertura do filme quando da troca de turno de 
trabalho, mas também sobre os demais membros daquela sociedade. Nesse sentido, o corpo feminino das dançarinas e prostitutas em seus contorcionismos mostra-se igualmente sob os efeitos da mecanização da sociedade (Debord, 1997 Kracauer, 2009).

O grave acidente com uma das máquinas que então provocou a morte de operários fez nascer uma revolta já latente dentre a massa de trabalhadores. As insatisfações dos operários frente ao ritmo frenético de trabalho imposto pelas máquinas eram conduzidas em forma de culto religioso, culto este comandado pela figura feminina de Maria a anunciar, tal como uma sacerdotisa, o surgimento de um líder a libertar os operários das amarras opressivas das máquinas. Assim, o filme parece estabelecer uma contraposição entre religião e ciência. Enquanto a crença religiosa dos operários sublima seus sofrimentos e agruras na esperança de um futuro redentor a libertá-los do jugo das máquinas, a ciência, encarnada na figura do cientista Rotwang, trabalha em prol do aperfeiçoamento das próprias máquinas. Daí o fato de uma das mãos do cientista ser mecânica e, ao fim e ao cabo, ele encarnar a vilania da trama. O culto religioso, no entanto, não consegue impedir a revolta quando da ocorrência do acidente a ceifar a vida dos operários. Os operários decidem destruir as máquinas como uma forma desesperada de libertação, a despeito dos argumentos e discordância do líder dos operários, cônscio da importância das máquinas para a existência dos próprios operários. Eram eles, os operários, os braços a fazer funcionar aquela engrenagem social. A massa de operários revoltosos, por seu turno, decide agir de maneira impulsiva, sem meditar acerca das consequências e implicações do ato (sobre a questão das massas como entidades autônomas ver Le Bon, 2008).

No entanto, tal revolta, uma vez descoberta pelo proprietário da indústria com a ajuda do cientista, é utilizada para gerar discórdia dentre os próprios operários revoltosos. O cientista cria uma espécie de androide a duplicar a figura de Maria. A Maria mecanizada desestimula a turba de operários revoltosos quanto a qualquer ação de destruição das máquinas e, assim, divide as opiniões e o movimento. Note-se, no entanto, que o corpo mecanizado de Maria a retira da dimensão sagrada e a torna uma figura profana ao exibir-se como dançarina, incitando os desejos sexuais masculinos. 
Em função dos encontros e desencontros e quiproquós diversos, Freder acaba por encarnar a figura do messias anunciada por Maria nos cultos religiosos. Maria havia sido sequestrada por Rotwang quando da criação da falsa Maria, a mecanizada. Mas, a despeito disso, ocorre uma destruição parcial de uma das máquinas, o que acaba por causar a inundação da vila dos operários e, assim, coloca a vida das crianças e filhos dos operários em perigo. Dada a tragédia iminente, a ação conjunta da verdadeira Maria e de Freder, com a ajuda de Josaphat, as crianças são salvas. A falsa Maria foi desmascarada e aprisionada pelos operários enfurecidos e queimada em uma fogueira, momento em que se revela a máquina sob a pele de Maria.

Metropolis, de Fritz Lang, e Tempos Modernos, de Charles Chaplin, os filmes retratam o avanço tecnológico ocorrido nos inícios do século XX e que causou um aprofundamento da subordinação do trabalho ao capital, além de graves consequências não só no plano da economia política, mas também quanto ao modo de formação da própria subjetividade na sociedade moderna (Simmel, 2013). Assim como os corpos dos operários e das mulheres no filme de Fritz Lang salientam os efeitos da máquina, a própria ação corporal de Chaplin em seu filme também ressalta tal influência.

Tanto Charles Chaplin quanto Fritz Lang retrataram as consequências da industrialização e do processo de mecanização do trabalho. O filme de Chaplin, por seu turno, estende tal crítica para o plano da vida cotidiana. Mesmo com a possibilidade de utilizar a sonorização em seu filme, Chaplin optou por utilizar o som como um meio eficaz a ressaltar os efeitos perversos da mecanização da sociedade nos próprios corpos dos indivíduos. Somente as máquinas emitem sons em seu filme. Um paralelo entre os dois filmes, Metropolis e Tempos Modernos, faz ressaltar a temática da mecanização da sociedade e seus efeitos desumanizadores, não só em função da repetitividade das ações e gestos, mas principalmente pela sensação de distanciamento da sensibilidade (em Fritz Lang) e da natureza (em Charles Chaplin). 


\section{Um mundo em desordem}

Playtime, de Jacques Tati, de 1967, é uma sátira acerca do mundo moderno protagonizada por um personagem que se revela incapaz de adequar-se às mudanças operadas pela mecanização da vida cotidiana. As cenas iniciais do filme, e não por acaso, se passam em um aeroporto, o "não lugar" por excelência destinado a excluir toda possibilidade de um convívio humano mais aproximado na medida em que é um espaço previamente demarcado e semelhante e todas as cidades do mundo. Hulot, o protagonista, é um personagem a encarnar o desconforto gerado por tais espaços, a despeito de a cidade onde se passa a trama ser a cidade natal de Hulot, Paris.

Tal paradoxo parece ser levado às últimas consequências quando da chegada de turistas americanos, ávidos por conhecer um "outro lugar", a sensação de estranhamento mostra-se um tanto quanto inapropriada e forçada. Os cenários apresentados no filme, explicitam, de fato, da cidade de Paris. Poderia ser qualquer outra cidade. Somente em um momento, e muito brevemente, há uma indicação de Paris. É o momento em que surge, refletida em uma das portas de uma agência de turismo, a imagem da Torre Eiffel. As peculiaridades e singularidades então buscadas pelos turistas americanos acerca da capital francesa, no entanto, são identificadas em seus eventuais clichês. A cena da turista americana que, ao encontrar uma vendedora de flores em uma esquina, intenta registrar fotograficamente por tratar-se de algo tipicamente parisiense é inviabilizado em função do intenso tráfego de pedestres e de turistas.

A sátira do filme em relação a uma Paris modernizada desdobra-se quando do comentário de uma das turistas americanas acerca do trânsito e do tamanho dos carros: com carros menores, o congestionamento diminui. Mas a modernidade da arquitetura da cidade, algo a igualar todas as cidades, revela-se menos pela sua funcionalidade e mais como dispositivos a inviabilizar os contatos humanos. $\mathrm{O}$ protagonista do filme, o típico parisiense Hulot, com suas andanças erráticas por entre aquela arquitetura labiríntica, assemelha-se ao Carlitos de Tempos Modernos, de Chaplin, ou seja, é retratado como um ser estranho a emperrar a engrenagem. Juntamente com a ideia de engrenagem, deve-se destacar a questão do espelhamento. 
Os ambientes vazados propiciados pelo excesso de vidraçaria, e utilizados de maneira recorrente naquele tipo de arquitetura, fazem com que os desencontros entre os indivíduos sejam exacerbados, embora o objetivo seja, evidentemente, viabilizar uma aproximação maior. Mas tal reverso de funções são explicitadas, justamente, dada a inadequação e o deslocamento do próprio personagem Hulot. É ele quem faz aparecer o desconforto gerado pela modernidade e pela tendência irrefreável do mundo moderno em promover a mecanização da vida.

O desconforto e a não adequação dos indivíduos na modernidade são explicitados no filme quando da cena a narrar a chegada de Hulot em um daqueles prédios do setor moderno da cidade a fim de entregar um bilhete para alguém. 0 próprio porteiro do prédio, um senhor já com certa idade, parece ainda não dominar as engrenagens de comunicação instaladas na portaria para acionar os diferentes escritórios. Uma vez feita à comunicação, o porteiro insiste que Hulot aguarde sentado até a chegada do funcionário. Mesmo quando este já é visível no longo corredor que dá acesso à portaria, o porteiro reafirma a necessidade de se aguardar sentado, a despeito de Hulot mostrar-se ansioso e um tanto quanto angustiado por já ouvir os passos de aproximação do tal funcionário. A cena se desdobra quando o tal funcionário conduz Hulot até uma sala envidraçada com algumas poltronas que, a princípio, se mostram confortáveis. Mas quando ele se senta em uma delas, o corpo de Hulot parece afundar até deixá-lo completamente desconfortável. O mote do desconforto prossegue na trama do filme quando, dentro desse prédio moderno, Hulot se perde como em um labirinto. Sempre em busca daquele funcionário que o recebeu antes, nunca consegue alcançá-lo, mesmo quando o vislumbra de longe por meio das paredes envidraçadas. Tudo parece estar tão próximo e ao mesmo tempo distante quando se trata de se estabelecer alguma forma de comunicação direta.

Uma crítica à mecanização da vida moderna chega ao seu ápice no filme quando Hulot, ainda perdido naquele prédio, se encontra no andar onde ocorre uma feira de utilidades domésticas. Um conjunto variado de objetos e aparelhos supostamente criados para facilitar a vida cotidiana são expostos aos turistas e visitantes. 0 comportamento de Hulot, no entanto, faz acentuar, de fato, a inutilidade daqueles aparelhos ali expostos. Na verdade, não são as eventuais dificuldades da vida moderna 
que motivaram e engendraram a invenção daqueles aparelhos como solução, mas os próprios aparelhos parecem criar as necessidades antes sequer imaginadas pelas pessoas em sua vida cotidiana. A modernidade mecanizada impôs a sua própria lógica perversa na equação entre problemas e soluções.

Hulot, como já ressaltado, se perde entre portas de vidro, escadas rolantes e elevadores, seguindo trajetórias não previstas e provocando inúmeras confusões. Vive papéis distintos a cada momento quando, por exemplo, é confundido por turistas como um dos vendedores na feira de eletrodomésticos. É o momento em que o seu duplo surge no filme. A ideia do duplo, dessa forma, junta-se à questão do espelhamento e reforça os desencontros. Inversamente à ideia da racionalidade apregoada pela modernidade, o que aflora a partir da mecanização da vida é a própria irracionalidade (Marcuse, 2015). Quando Hulot posta-se em uma dada posição daquela arquitetura de paredes envidraçadas para procurar o funcionário que o recebeu na entrada do prédio, ele observa com certo estranhamento a forma como o mundo do trabalho divide os diversos funcionários daquela empresa em compartimentos indiferenciados, revelando-se como um labirinto indecifrável para o personagem. E aqui, mais uma vez, vale a inadequação de Hulot frente essa realidade contemporânea. Quando Hulot, finalmente, parece avistar o funcionário em um outro prédio vizinho através das paredes envidraçadas, novamente emerge a questão do espelhamento a causar novos enganos. Na realidade, tratava-se de um mero reflexo, só que, desta feita, a tornar distante o que de fato estava próximo.

O conjunto arquitetônico moderno por onde transita Hulot parece indicar uma homogeneização dos espaços. Tal argumento é reforçado quando do aparecimento da agência de turismo e sua decoração com cartazes enfileirados a mostrar diferentes países. O que se vê, no entanto, é exatamente o mesmo prédio composto de uma enorme e impessoal fachada de vidro. Há apenas alguns pequenos elementos diferenciadores que tentam conferir identidade a cada local. Assim, para o Brasil, por exemplo, temos um índio e palmeiras. Para o México, um sol asteca e uma pirâmide e, para a Inglaterra, um ônibus vermelho de dois andares. A visão do turista parece ser o olhar a partir do qual se dá a estruturação do filme. Mas ao invés da visão diferenciadora de cada localidade, reforça-se a visão do mesmo, do sempre igual. A 
Paris dos monumentos, do Sacré Cœur, da Torre Eiffel e do Arco do Triunfo é deixada de lado em prol dessa Paris modernizada que poderia ser qualquer outra cidade, embora os reflexos de tais ícones parisienses ainda apareçam de maneira breve nos painéis de vidro a dominar a cena dessa cidade nova, como fantasmas que assombram e tendem a evocar fugazmente o seu passado (Kracauer, 2009).

O tempo histórico não é importante nessa cidade que busca incessantemente o moderno: ela foge ao olhar e se esmaece nos reflexos de uma modernidade pretensamente universal. A feira de produtos eletrodomésticos reforça tal sensação. Vassouras munidas de lanternas para melhor se varrer embaixo dos móveis, segundo o expositor, que apresenta seu produto com todo um gestual a assemelhar-se ao de um mágico realizando um dos seus mais preciosos truques. Portas que batem sem ruído, pois, quando batemos uma porta, esperamos o ruído a anunciar estrondosamente a nossa saída. Se tal ruído não acontece, há algo de frustrante e inútil no gesto. Além de outras mercadorias que tentam somar aspectos novos a objetos já há muito conhecidos. Nas palavras de uma das turistas que visita a exposição: "é tudo americano". Mas qual a novidade da feira se aqueles turistas são, eles mesmos, americanos?

Um outro momento inusitado do filme se dá quando, ao anoitecer, um restaurante aparece como cenário. As confusões e quiproquós que aí ocorrem, por sua vez, não se dão por conta da ação de Hulot, mas sim em função das disfunções técnicas próprias da mecanização da vida. Os dispositivos técnicos que singularizam a modernidade do restaurante simplesmente não funcionam como deveriam funcionar, desde a iluminação até um pressuposto atendimento padronizado por parte dos garçons. A banda de jazz desiste de tocar, a comida acaba, os clientes amontoam-se e os empregados tornam-se ineficientes. Quando a porta de vidro que dá acesso ao restaurante é destruída, o artifício do porteiro ao dissimular a existência da porta de vidro (já que transparente) reforça a sátira do filme acerca da modernidade. Por fim, a queda dos painéis de madeira junto à pista de dança instaura uma desordem completa. As máquinas cessam sua influência e, assim, faz-se emergir o humano. Os personagens passam então a movimentar-se de uma forma menos mecânica e mais humana. Aliás, a música tocada pela banda de jazz e a dança no salão central do 
restaurante por parte dos clientes tendem a assimilar-se às danças tribais, como se o fracasso da modernidade estampada nos apetrechos técnicos ali falhados redundasse em um retorno a um primitivismo mais humano.

A visão dos interiores e, por consequência, da privacidade dos moradores, converte-se em outro elemento central do filme. Em vários momentos, somos colocados face aos seus paradoxos: a transparência a propiciar o olhar invasor. O vidro, dessa forma, é o principal material a compor o conjunto arquitetônico do novo bairro modernizado, mas, ao mesmo tempo, apresenta os reflexos da cidade antiga. Quando Hulot encontra o tal funcionário por quem buscava desde o início do filme e este, por sua vez, o conduz até sua residência, as salas de estar dos distintos apartamentos são vazadas, podendo-se observar os moradores em seu interior. É como se as salas de estar fossem telas de televisão para os transeuntes na rua, uma espetacularização da vida privada (Debord, 1997).

A transformação da cidade moderna em uma sucessão de lugares desprovidos de identidade e de historicidade, já desde o início do filme, confunde o espectador quanto a uma identificação dos diferentes locais. No início do filme, por exemplo, o espaço mostrado é, afinal, um hospital ou um aeroporto? O prédio da empresa para onde se dirige Hulot parece abrigar diversos tipos de atividade, mas os espaços são absolutamente iguais em todos os andares. A lanchonete pode ser facilmente confundida com uma farmácia. O ápice dessa proposta de ressignificação do mundo a partir do deslocamento do olhar surge ao final do filme. Em uma cena cada vez mais corriqueira nas grandes cidades, a imagem de congestionamento de automóveis na rotatória de uma via é a alegoria da espetacularização do mundo. O movimento lento e coordenado dos automóveis e a presença humana no entorno (crianças segurando balões ao lado dos pais, vendedores de doces, etc.), aliados à música de inspiração circense, apresentam ao espectador uma visão quase surrealista, uma subversão da realidade a partir da reorganização de seus elementos: o deslocamento dos automóveis se transforma em inusitado carrossel a centralizar o cenário, cujos elementos ressignificados materializam um grande parque de diversões. A desordem do mundo ganha uma aura de espetáculo por meio da ilusão. 


\section{O jogo da ilusão}

Se as máquinas já se impõem como um poder regulatório das atividades humanas em Metropolis(2026) e em Tempos Modernos(1936), em Matrix, das irmãs Wachowski, de 1999, tal dominação radicaliza-se na medida em que o ser humano é reduzido e recriado para cumprir o papel de mero fornecedor de energia para as próprias máquinas. A dureza e a crueldade de uma tal realidade, no entanto, devem ser arrefecidas, de alguma forma, para tornar a dominação das máquinas não só viável, mas também algo mais facilmente aceitável por parte dos humanos. Daí a criação de "Matrix", uma realidade virtual destinada a iludir os próprios seres humanos como controladores e donos de seus destinos. Embora seja tentador relacionar o mundo de ilusão de "Matrix" com a questão da ideologia necessariamente implicada nos processos de dominação no mundo moderno (Marx \& Engels, 1999), tal contração, por seu turno, oblitera outros tantos aspectos relacionados com essa articulação complexa entre realidade e ilusão. O próprio cinema como forma de manifestação artística intimamente relacionada com a questão das máquinas, nesse sentido, converte-se em tema central nesse jogo de ilusões que é a vida em sociedade (Benjamin, 2012 Kracauer, 2009).

Após uma batalha crucial entre humanos e máquinas no ano de 2199, "Matrix", surge como uma espécie de programa de computador criado pelas máquinas e destinado a iludir os seres humanos na medida em que se convertem em potenciais fontes de energia para que as próprias máquinas exerçam seu poder. A subsunção do trabalho em relação às máquinas tal como esquadrinhada por Marx ganha aqui uma versão radical. Dentro da cronologia da narrativa do filme, tal situação de dominação das máquinas sobre humanidade já perdura há dois séculos, sem que a própria humanidade tenha tomado plena consciência de tal dominação, salvo alguns grupos rebeldes já desconectados e libertos da rede. Em "Matrix"; os indivíduos interagem entre si como em um teatro de sombras, mas não no sentido de uma projeção em uma parede, e sim como um mecanismo inserido diretamente em suas mentes. Em última instância, assim se define "Matrix", uma realidade virtual a simular uma realidade 
social nos moldes daquela existente em finais do século $\mathrm{XX}$ a exigir de cada indivíduo um comportamento disciplinar.

Quase toda a humanidade, por meio de variados artefatos cibernéticos espalhados pelo corpo, está conectada à "Matrix" e faz com que os diversos indivíduos a tomem como a própria realidade. Um dos grupos de rebeldes liderado por Morpheus passa anos procurando por aquele que, acredita-se, seja capaz de destruir "Matrix" e, assim, libertar a humanidade do jugo das máquinas. Vale salientar, nesse sentido, que o nome Morpheus é uma referência à divindade do sono e dos sonhos, portanto, a um personagem que busca dar uma forma a uma outra realidade ainda inexistente.

Ora, não é difícil associar a essa distopia estampada em Matrix o tema religioso do messias redentor e libertador. O "escolhido", dessa forma, é alguém ainda não consciente da situação de subjugação às máquinas, mas que, de alguma forma, apresenta um comportamento de desconforto e de não adequação às normas vigentes no mundo virtual. Anderson, conhecido por Neo, é um hacker que ganha a vida pirateando programas de computador. Embora seja empregado em uma corporação, seu comportamento um tanto quanto desviante e não disciplinado faz com que a sua perspectiva do mundo se mostre distorcida, daí sua atividade como hacker. 0 encontro entre $\mathrm{Neo}$ e os rebeldes liderados por Morpheus se dá em um momento capital para uma revelação impactante: o instante da sonolência, momento em que realidade e sonho se embaraçam de tal maneira a ponto de não se saber exatamente o que é realidade e o que é sonho. Como se um túnel ou alguma espécie de portal se abrisse e promovesse um baralhamento entre realidade e sonho. Dado que "Matrix" é um programa de computador a criar uma realidade virtual, é por meio do computador de Neo que o contato inicial se estabelece. A sonolência de Neo e a sensação de entrar em um túnel a reverter a lógica da própria realidade, como em Alice nos país das maravilhas, é reforçada a partir do recado na tela do computador: "Siga o coelho".

Uma vez estabelecido o contato com os rebeldes e revelada a ilusão de "Matrix", Neo é desconectado, libertado das máquinas e conduzido para o "mundo real". O choque com aquela realidade mais cruenta faz com que Neo sinta náuseas, fato a indicar que alguma forma de ilusão sempre se faz necessária para dotar a vida de algum sentido e torná-la viável. Mas o momento imediatamente anterior à revelação é 
mais expressivo do jogo de ilusão contido na trama do filme. Uma vez explanada por Morpheus a história da dominação das máquinas sobre a humanidade, e do que se trata efetivamente "Matrix", Neo se vê em uma encruzilhada: ou o mundo de ilusão, ou a realidade perversa da dominação das máquinas. A pílula azul o preservará no mundo de ilusão, já a pílula vermelha o levará direto para a realidade. No entanto, cabe observar, a pílula vermelha também carrega consigo algo de ilusório dentro da própria economia interna da trama: a crença na necessidade de se combater as máquinas e uma consequente libertação da humanidade. É isso que parece conferir, ao fim e ao cabo, um sentido para a própria vida daqueles rebeldes. Mas, por outro lado, essa opção que é oferecida por Morpheus a Neo não é garantia de absolutamente nada. Basta lembrar o papel de um outro personagem a cumprir o papel de vilão na trama: Cypher. É ele quem se arrepende de ter saído de "Matrix" e, em função de tal arrependimento, participa de um conluio para entregar Morpheus e seus rebeldes às máquinas perseguidoras. Cypher faz, portanto, uma opção deliberada pelo mundo de ilusão, como se a consciência da ilusão não interferisse em seu funcionamento como mecanismo de adequação ao mundo.

No mundo de ilusão de "Matrix", os sentidos são responsáveis por convencer a mente a baralhar ilusão e realidade, não havendo outra possibilidade além daquela ilusão apresentada. A explicação de Morpheus a Neo exemplifica a questão: "Você nasceu numa prisão e não é capaz de cheirar, provar o gosto das coisas ou tocar: é uma prisão para a mente". O prazer desencadeado por esses sentidos nos faz ter a sensação de que o que estamos experimentando naquele determinado momento é o que há de mais real. Ao sair da cápsula que enclausura seres humanos e suga suas energias, Neo sente dores nos olhos ao abri-los. Ao perguntar a Morpheus o porquê da dor, Morpheus responde categoricamente que a dor só tem um motivo: Neo nunca tinha usado seus olhos de verdade. A visão, até então, tinha sido enfeitiçada por uma ilusão, como uma espécie de Medusa a enfeitiçar suas vítimas e, assim, petrificá-los, não Ihes conferindo uma existência, mas sim a presença em um não-lugar. Neo abre seus olhos para uma nova realidade. Tudo que Morpheus the havia explicado passa da possibilidade a uma nova realidade, porque agora ele consegue ver além da ilusão de "Matrix". 
O telefone é um aparelho de comunicação amplamente utilizado no filme Matrix. É por meio dele que os rebeldes se comunicam, mas é somente por meio de telefones com fio que se dá a transição entre o mundo real e o mundo virtual. $A$ contraposição entre os telefones móveis e os telefones com fio tende a contrastar níveis diferenciados de tecnologia. A tecnologia mais atrasada, dessa forma, é que viabiliza aos rebeldes a intromissão não autorizada e a própria fuga de "Matrix". Inversamente, pode-se dizer, todo o avanço tecnológico tende a oprimir cada vez mais os humanos até reduzi-los a máquinas e, nesse sentido, o resgate ou a preservação de uma tecnologia mais atrasada parece conter algum elemento mais humano. O próprio filme, nesse sentido, não pode ser descartado do tema ali fabulado. A relação entre realidade e imaginário tal como o cinema impôs ao longo do tempo em uma sociedade de massa é reproduzido no filme a partir da relação entre o mundo real e "Matrix". Toda a elaboração de um mundo futurista comandado por máquinas está diretamente relacionada não só com o processo de mecanização imposto pela sociedade moderna, mas também com o próprio cinema como forma de manifestação artística articulado com a sociedade de massas (Kracauer, 2009). Matrix, nesse sentido, é mais um momento da produção cinematográfica a expressar por seus próprios meios as novas etapas quanto ao avanço da dominação das máquinas e da subsunção do trabalho ao capital.

\section{A subjetividade como mecanismo}

Os processos de subjugação da humanidade gradualmente operados pelas máquinas e cada vez mais aprofundados no mundo moderno, e que foram tematizados no cinema em diversos e variados filmes, focalizam os avanços tecnológicos como o mote a explicitar a normatização de um ponto de vista disciplinar dos corpos. No filme de Spike Jonze, Ela, de 2013, os avanços tecnológicos atingidos pela humanidade nos últimos vinte anos são tematizados ao se considerar a dominação por parte das máquinas ao aturarem diretamente no plano subjetivo dos indivíduos. O filme narra o drama existencial do solitário Theodore, empregado de uma corporação que tem como produto peculiar consolar e ajudar, por meio do envio 
de cartas a serem postadas nos correios, diferentes indivíduos que eventualmente sofram perdas de parentes e entes queridos, ou que necessitam de ajuda para expressar seus mais profundos sentimentos em relação a outra pessoa. 0 distanciamento cada vez maior entre as pessoas e a consequente solidão transformaram-se, ao que parece, em um problema de ordem existencial. Já aí revelase certa incapacidade afetiva por parte de indivíduos modelados por uma sociedade marcada fortemente por certo nível de mecanização. 0 talento de Theodore reside justamente em colocar-se na perspectiva do cliente e, assim, expressar mais facilmente a afetividade demandada e que não é possível de ser explicitada diretamente pelo eventual cliente.

Embora o aparato tecnológico existente na narrativa do filme já viabilize a composição das cartas não mais pelo processo tradicional da escrita, mas sim por meio da narração em voz alta, inclusive com a digitalização das missivas a imitar letras cursivas, conferindo, assim, um caráter mais pessoal e íntimo próprios de narrativas carregadas de sentimentalidades, o dado fundamental de tal tarefa reside justamente na capacidade desenvolvida por Theodore de atingir plenamente as expectativas do destinatário a ser homenageado ou consolado. Tal como uma espécie de médium, Theodore parece incorporar de tal modo a voz dos clientes a ponto de satisfazer as carências e angústias mais íntimas dos variados destinatários. Em certa passagem do filme, quando um dos colegas de trabalho elogia Theodore pelas suas cartas, ele arrisca um palpite para tal sucesso: Theodore possui um lado sentimental exacerbado, uma espécie de lado feminino mais aguçado.

Mas, a despeito da sua performance e da sua capacidade em apreender a personalidade de alguém e, assim, colocar-se no lugar do outro, o próprio Theodore não consegue superar a sua própria dor ocasionada pelo divórcio e o fim de seu casamento. A tecnologia parece ser, novamente, o único recurso a que se possa lançar mão para um eventual e efêmero arrefecimento desse vazio, seja por meio do sexo anônimo por telefone, seja por meio de jogos virtuais ou, no limite, um encontro previamente agendado por meio de redes de relacionamento entre pessoas solitárias. É nesse momento do filme que um novo programa de computador é lançado por uma corporação de softwares, uma solução para preencher o vazio na vida afetiva de 
Theodore e de outros milhares de usuários solitários. Trata-se de um inusitado e sofisticado sistema operacional capaz de adequar-se aos anseios e necessidades afetivas do usuário. Na medida em que o sistema operacional responde de maneira sub-reptícia as expectativas do usuário, este tende a iludir-se quanto às eventuais compatibilidades de ordem afetiva e mesmo amorosa a serem criadas. No caso de Theodore, o sistema operacional se atribui o nome de Samantha. Como o próprio nome indica, ela se fará presente em todos os momentos e lugares em que Theodore se encontre, seja no seu computador doméstico ou do trabalho e, principalmente, no seu telefone móvel. Tal onipresença, por seu turno, deve cumprir o objetivo e o papel do sistema operacional: aliviar as dores da solidão de seus usuários.

Mas como o nome Samantha também implica a ideia de término e limite, há um prazo de validade para a vigência do software. E é precisamente no momento da perda de Samantha que Theodore percebe mais claramente a ilusão até então vivenciada por ele ao longo de alguns meses. De uma forma otimista, o filme parece indicar ao seu final que, na realidade, e a despeito das incertezas e eventuais dores implicadas em um relacionamento afetivo entre humanos, são somente tais relacionamentos que podem preservar algo propriamente de humano em cada indivíduo. O papel do software seria, portanto, para além de combater a solidão, criar uma ilusão para o não enfrentamento de tais incertezas e dores.

O filme Ela, dessa forma, não é uma distopia futurista onde os sentimentos são banidos em um mundo dominado opressivamente pelas máquinas, mas sim uma projeção de um olhar sobre a nossa própria realidade ao enfocar como as relações afetivas vêm se transformando ao longo do tempo. A tecnologia, de fato, acentua e facilita algumas fugas, mas não as inventa. Dentro desse quadro futurista a expressar uma nova forma de dominação das máquinas sobre a humanidade, nota-se também uma nova maneira de se abordar tal relação: a ilusão de um mundo virtual aloja-se cada vez mais na própria subjetividade dos indivíduos por meio de uma adaptação das máquinas (os softwares) aos anseios e necessidades afetivas de cada indivíduo.

Os figurinos, a decoração, as estampas e as cores dos cenários do filme, por outro lado, priorizam tons mais quentes como o vermelho, o laranja e o amarelo, criando ambientes internos a partir de referências oriundas do passado, embora o 
cenário externo ganhe um aspecto mais propriamente futurista na arquitetura e no meio urbano. Mesmo alguns dos dispositivos tecnológicos presentes no filme tiveram seus designs inspirados em acessórios da década de 1940. A tecnologia na Los Angeles futurista do filme de Spike Jonze é uma tecnologia de acessórios mínimos. O computador de Theodore, por exemplo, é composto apenas por um monitor, sem teclado, mouse, caixas de som ou outros equipamentos periféricos, além de ser ativado unicamente por comandos de voz. Outro aspecto importante no universo de Ela é a quase ausência de automóveis. Na Los Angeles de Jonze, as pessoas se locomovem pela cidade principalmente por transportes coletivos, como trens e metrôs, além de caminharem e andarem de bicicleta. Mas tal aspecto coletivo constante no filme só reforça a solidão ensimesmada e generalizada dos moradores da metrópole (Simmel, 2013).

O avanço tecnológico propiciou uma grande revolução na história da humanidade, criando um novo elemento: a rede telemática. Um espaço de intensa personificação configurada de tal modo a permitir a troca rápida de informações por meio de uma máquina. A partir disso, novos meios de interação e formas de sociabilidade estão sendo constantemente organizados. $O$ crescente florescimento das técnicas possibilitou a interação em tempo real. Entretanto, a ausência do contato face a face, inicialmente, traz a inversão de formas tradicionais de sociabilidade a indicar certa fragilidade desses novos meios. A primeira interação se dá em função de interesses comuns para, depois, haver de fato algum contato físico. O tema do filme explora, portanto, as insuficiências afetivas geradas a partir do vínculo estabelecido entre o indivíduo contemporâneo e a onipresença da tecnologia, dissecando a dependência mútua dessa relação e comumente observado no panorama da sociedade. Todavia, este elo tende a uma atuação unidimensional, trivializando o indivíduo em prol da influência do meio tecnológico que, agora "personificado", influencia o desprezo crescente pela sociabilidade física e do contato social. Tal dependência, dentre tantos efeitos causados, culminou na gênese de indivíduos solitários, insociáveis e descontentes com os relacionamentos afetivos estabelecidos face a face, buscando no meio virtual, por conseguinte, a relação perfeita e superficial construída por certas expectativas. O indivíduo sente-se desprovido de significação 
quanto à sua existência e propósito. A sensação de perda de significação precede o sentimento de apatia, ocasionando um decréscimo da própria consciência. 0 atrofiamento da consciência induz o indivíduo a acreditar que a tecnologia seja capaz de suprir seus desejos e, assim, proporcionar maior afetividade e alegria. No entanto, esta situação agrava ainda mais o problema existencial do indivíduo, uma vez que uma consciência reduzida só tende a fomentar a perda do senso de significação. $O$ tratamento deste ciclo de decréscimo da consciência só se dará com êxito na medida em que o indivíduo voltar a ser o centro de si mesmo, ou seja, libertando-se das amarras e ilusões geradas pela tecnologia. O indivíduo, uma vez consciente de sua própria liberdade de escolha, desde que esta seja uma opção consciente, conquistará o autoconhecimento: "o que eu quero e o que eu realmente sou". No filme Ela, o desencanto de Theodore com o sistema operacional possibilitou a sua retomada de laços afetivos "reais". Assim, o potencial para desempenhar a auto regulação só será concedido ao indivíduo quando ele se libertar e se descobrir como pessoa autônoma e responsável por suas ações.

\section{Considerações finais}

Na medida em que o cinema se converte em uma forma de expressão artística fundamentalmente assentada na máquina a gerar e produzir representações acerca da realidade, a própria linguagem cinematográfica criada e aperfeiçoada ao longo do tempo tende a expressar os diferentes momentos não só quanto ao papel da tecnologia em relação às mudanças então geradas, mas também quanto a uma configuração da própria humanidade em seu aspecto existencial. O cinema, nesse sentido, propicia uma reflexão acerca do papel da tecnologia no mundo moderno na justa medida em que ele, o próprio cinema, só se tornou viável em função das máquinas. O enfoque aqui dado a alguns filmes de diferentes épocas que, fundamentalmente, tematizaram os avanços tecnológicos e suas consequentes implicações, também levou em conta as inovações que cada um de tais filmes trouxe do ponto de vista da própria linguagem cinematográfica. Metropolis, nesse sentido, para além de um desfecho feliz a unir o cérebro e os braços da sociedade a partir de uma intervenção do coração, acentua negativamente o papel e o domínio das 
máquinas dentro de uma atmosfera expressionista a conferir certa dramaticidade à trama. Os cenários do filme, dessa forma, tendem a apequenar o elemento humano e, ao mesmo tempo, oprimi-lo em pequenos espaços em função dos embates entre aqueles que dominam e os muitos dominados. As máquinas é que intermediam tal dominação.

Em Playtime(1967) e, embora o filme tenha como tema a expansão tecnológica para além do ambiente de trabalho, aponta para a homogeneização dos espaços como uma decorrência direta daquela expansão, inclusive ao indicar uma realidade ilusória. A efetivação de um mundo ilusório como meio de dominação radical das máquinas sobre a humanidade é precisamente o tema de Matrix. A partir de novos apetrechos técnicos então desenvolvidos, o filme parece se aproveitar das novas possibilidades então geradas para inverter a própria lógica de uma realidade, ou pôr em dúvida a existência de uma realidade tal qual apreendida. 0 mundo das máquinas, tal como o próprio cinema, propicia a invenção de realidades. A ilusão também é o tema tratado em Ela, não como uma distopia, mas como um jogo a ser jogado no plano da subjetividade. $\mathrm{O}$ aparato tecnológico exerce seu poderio não só no plano exterior do mundo do trabalho ou nos espaços urbanos a modificar a própria arquitetura, mas também age, e isso é fundamental, no plano subjetivo, na dimensão psicológica ao baralhar o real e o virtual.

\section{Referências bibliográficas}

ADORNO, T. 2007. As estrelas descem à terra: a coluna de astrologia do Los Angeles Times; um estudo sobre superstição secundária. Trad. Pedro Rocha de Oliveira. São Paulo: Ed. Unesp.

BENJAMIN, W. et al. 2012. Benjamin e a obra de arte; técnica, imagem, percepção. Trad. Marijane Lisboa. Rio de Janeiro: Contraponto.

BERMAN, M. 2007. Tudo que é sólido desmancha no ar; a aventura da modernidade. Trad. Carlos Moisés \& Ana Maria Ioriatti. São Paulo: Companhia das Letras.

DEBORD, G. 1997. A sociedade do espetáculo. Trad. Estela Abreu. 4a ed. Rio de Janeiro: Contraponto. 
ENGELS, F. 2008. A situação da classe operária na Inglaterra. Trad. B. A. Schumann. São Paulo: Boitempo.

HANSEN, M. B. 2004. "Estados Unidos, Paris, Alpes: Kracauer (e Benjamin)". In: Charney, L. e Schwartz, V. (orgs.). O cinema e a invenção da vida moderna. Trad. Regina Thompson. 2a ed. São Paulo: Cosac \& Naify, p. 405-450.

KRACAUER, S. 2009. O ornamento da massa. Trad. Carlos Eduardo Machado \& Marlene Holzhausen. São Paulo: Cosac Naify.

LE BON, G. 2008. Psicologia das multidões. Trad. Mariana Sérvulo. São Paulo: Martins Fontes.

MARCUSE, H. 2015. O homem unidimensional; estudos da ideologia da sociedade industrial avançada. Trad. Robespierre de Oliveira, Deborah Antunes \& Rafael Silva. São Paulo: EDIPRO.

MARX, K. 2004. Manuscritos econômico-filosóficos. Trad. Jesus Ranieri. São Paulo: Boitempo Editorial.

e Engels, F. 1999. A ideologia alemã. 11a ed. Trad. José Carlos Bruni \& Marco Aurélio Nogueira. São Paulo: Ed. Hucitec.

SIMMEL, G. 2013. "As grandes cidades e a vida do espírito". In: Botelho, André (org.). Essencial sociologia. São Paulo: Penguin Classics/Companhia das Letras, p. 311-329.

Tramitação do artigo na revista Submetido: 05/01/2019

Revisões requeridas: 26/03/2019

Versão revista: $27 / 03 / 2019$

Aceito: $12 / 04 / 2019$ 